\title{
Survival analysis of young adults from a Brazilian cohort of non-small cell lung cancer patients
}

\author{
Jéssica Silva Nicolau ${ }^{1 \dagger}$, Rossana Veronica Mendoza Lopez ${ }^{1 \dagger}$, Carolina Terra de Moraes Luizaga², Karina Braga Ribeiro ${ }^{3}$, \\ Rosimeire Aparecida Roela ${ }^{1}$, Simone Maistro ${ }^{1}$, Maria Lucia Hirata Katayama ${ }^{1}$, Renato José Mendonça Natalino ${ }^{1}$, Gilberto de Castro Jr ${ }^{1}$, \\ Jose Eluf Neto ${ }^{2,4}$ and Maria Aparecida Azevedo Koike Folgueira ${ }^{1}$ \\ ${ }^{1}$ Instituto do Câncer do Estado de São Paulo (ICESP), Hospital das Clinicas HCFMUSP, Faculdade de Medicina, Universidade de Sao Paulo, Sao Paulo, \\ SP, 01246-000, Brazil \\ ${ }^{2}$ Fundação Oncocentro de Sao Paulo (FOSP), Sao Paulo, SP, 05409-012, Brazil \\ ${ }^{3}$ Faculdade de Ciências Médicas da Santa Casa de Sao Paulo, Sao Paulo, SP, 01238-010, Brazil \\ ${ }^{4}$ Departamento de Medicina Preventiva, Faculdade de Medicina, Universidade de Sao Paulo, Sao Paulo, SP, 01246903 , Brazil \\ †JSN and RVML contributed equally to this work.
}

\section{Abstract}

Background: The influence of age at diagnosis in non-small cell lung cancer (NSCLC) prognosis is unclear.

Objectives: To compare in a Brazilian cohort of NSCLC patients of different age groups: 1) The overall survival; 2) Clinical features and treatment options.

Methods: This is a retrospective cohort study using a hospital-based registry, for NSCLC patients registered in years 2000-2009. Patients were grouped into three age groups: Young adults (YA: < 40 years), middle-aged (MA: 40-64 years) and elderly (E: $\geq 65$ years). Kaplan-Meier was used to estimate overall survival and Cox regression for hazard ratios (HRs) and 95\% confidence intervals.

Results: 17,422 NSCLC patients were included: 370 YA (2.1\%), 8,697 MA (49.9\%) and 8,355 E (48.0\%). Compared with older age groups, the YA group had a higher proportion of females, patients diagnosed with adenocarcinoma and metastatic disease (63.2\%). Overall survival was longer in YA in the entire cohort and in all clinical stages (CSs) ( $p$ $<0.001$ ). For YA, higher education level was a good prognosis factor (compared with illiterate and incomplete elementary); advanced or metastatic disease (compared with early-stage disease) and treatment based in radiotherapy or chemotherapy (CT) (without surgery), compared with treatment combinations with surgery, were poor prognostic factors. Young men (but not women) had lower HR of death compared with older groups; YA had lower HR of death in all CSs compared with patients from older groups. A higher percentage of YA were treated with surgery or CT in early-stage disease compared with older groups. Besides that, YA and MA patients treated with surgery or CT had a better prognosis than elderlies. Conclusions: In this Brazilian cohort of NSCLC patients, most young individuals were diagnosed with metastatic disease. YA presented longer survival than older age groups in all CSs, but mainly in CS I/II and III, where some patients may achieve long remissions or cure.

Keywords: lung carcinoma, non-small cell lung cancer, young adult, survival, clinical features
Correspondence to: Maria Aparecida Azevedo Koike Folgueira

Email: maria.folgueira@fm.usp.br

ecancer 2021, 15:1279

https://doi.org/10.3332/ecancer.2021.1279

Published: $24 / 08 / 2021$

Received: 23/03/2021

Publication costs for this article were supported by ecancer (UK Charity number 1176307).

Copyright: (c) the authors; licensee ecancermedicalscience. This is an Open Access article distributed under the terms of the Creative Commons Attribution License (http:// creativecommons.org/licenses/by/4.0), which permits unrestricted use, distribution, and reproduction in any medium, provided the original work is properly cited. 


\section{Introduction}

Lung cancer is one of the deadliest cancers worldwide. In Brazil, lung cancer is one of the most common cancers and according to INCA (Instituto Nacional do Câncer - Brazilian National Cancer Institute) [1], 17,760 new cases in men and 12,440 new cases in women were estimated for 2020. Survival rates are highly dependent on clinical stage at diagnosis. In the USA, five-year relative survival rates for the years 2008 to 2014 , varied from $56 \%$ for patients with localized disease to $30 \%$ and $5 \%$ for patients with regional and metastatic disease, respectively. Unfortunately, as much as $57 \%$ of the patients are diagnosed with metastatic disease and only $16 \%$ and $22 \%$ are diagnosed with localized and regional disease, respectively [2].

Lung cancer is usually diagnosed in people older than 60 years. There is data showing that age-specific incidence rates of lung cancer rise steeply from around age 45 to 49, to reach the highest rates in the 80-84 age group for females and the 85-89 age group for males, in the United Kingdom [3], as well as SSER showing that most patients are diagnosed with lung cancer at ages 60-69 years (37\%), followed by 50-59 years $(25.2 \%)$ and $70-79$ years (22.9\%) in the USA. Nonetheless, $8.99 \%-11.6 \%$ of the cases occur in individuals with ages below 51 years [4, 5].

Some studies have compared clinical features of lung cancer among young and elderly individuals. In the younger age group, the frequency of women, African Americans and adenocarcinoma was higher [4-6]. There is also data showing that younger patients are more frequently diagnosed with metastatic disease, as compared to older patients [5].

In Brazil, an ecological study using population-based cancer registries, hospital-based cancer registries and the national mortality database, for the period 2000-2014, revealed that almost $60 \%$ of the lung cancer patients presented in the age interval of $50-69$ years, most were males (63.5\%) and diagnosed with adenocarcinoma histology (41.9\%) [7]. Among younger patients, aged 18-49 years, a larger proportion of women was detected. Unfortunately, more than $50 \%$ of the patients were diagnosed with metastatic disease and more than $30 \%$ in clinical stage (CS) III. This study showed that both incidence and mortality rates for women with lung cancer increased in more recent years [7].

There is conflicting data regarding the influence of age at diagnosis on lung cancer prognosis. It was reported that young patients with inoperable tumours have a shorter survival as compared to a reference group of older patients [8]. Some studies, however, found no age-related differences on survival [9-11], while others reported a longer survival for young adults (YA) compared with older age groups [4-6, 12, 13]. However, the cutoff age varied from 40 [5] to 50 years [14] and even though some studies have only evaluated non-small cell lung cancer (NSCLC) patients [5, 14], others have included both SCLC and NSCLC $[4,6,11]$. Some of these studies attributed the survival advantage in young patients to more aggressive treatments and a higher incidence of somatic mutations in therapy target genes, such as Epidermal growth factor receptor (EGFR) [4, 5].

In Brazil, lung cancer represents a great challenge. Patients are frequently diagnosed with advanced stage disease, probably due to a delay in diagnosis. In addition, there is a low frequency of patients receiving curative-intent therapy and molecular testing is not yet available to all patients [15]. Besides that, there is no data specifically evaluating young patients.

Hence, the main goal of the present study was to evaluate overall survival for YA, diagnosed with NSCLC, compared with older age groups, in a cohort of patients from Sao Paulo State, Brazil. The secondary goal was to compare clinical features and treatment options in different age groups.

\section{Material and methods}

A retrospective cohort study was performed using the hospital-based registry from Fundação Oncocentro de Sao Paulo (FOSP) [16], which gathers data from public hospitals, as well as from some private and philanthropic hospitals from Sao Paulo State, Brazil.

The inclusion criteria were (i) diagnosis of malignant neoplasm of the lung (International Classification of Diseases for Oncology, C34) in the period between 2000 and 2009; (ii) lung as the primary site; (iii) age $\geq 18$ years at diagnosis. The exclusion criteria were (i) diagnosis of small cell carcinoma, neuroendocrine tumour, atypical neoplasm, carcinoma in situ, rare tumours (less than ten cases) in the dataset; (ii) null followup; (iii) inconsistency in dates of diagnosis and death (negative follow-up). Both ii and iii were similarly distributed in the three age groups, with an incidence of less than $1.0 \%$.

Data were retrieved from 21,263 patients and the studied sample consisted of 17,422 patients, after exclusions due to inclusion and exclusion criteria. Data included information on sex, histological type, CS, date of diagnosis and last date of follow-up. Data were collected on 
a yearly basis, thus lost to follow-up was defined for those living patients that did not come to the hospital for 2 consecutive years, at the time of the latest data collection. For these patients, another attempt to establish their vital status consisted of the search of other public databases: Unified Health User Registration System (CadSUS), National Register of the Deceased (CNF) and Individual Entity Registry (CPF). In CadSUS and CNF, the information obtained was the patient date of death, whereas in the CPF consultation, only the year of death was obtained, and 1 July was standardised as the last follow-up date, for all cases found in a specific year. In the end of this search, 195 cases remained as lost to follow-up (1.11\%) (Figure 1).

For this study, YA were those patients diagnosed with cancer between 18 and 39 years old [17]. Elderly patients (E) were those aged 65 or over ('World Population Ageing 2019 Highlights', United Nations, Department of Economic and Social Affairs, Population Division (2019) World Population Ageing 2019: Highlights) [18] and middle-aged (MA) were patients aged 40-64 years.

Clinical staging, based in the American Joint Committee on Cancer (AJCC) Cancer Staging, was retrieved from the database. In the period of the study (2000-2009), both AJCC 5th (1997) and 6th (2002) editions were effective; however, lung cancer staging criteria were kept unchanged in these editions.

Descriptive statistics were calculated for all variables. Mean, median, standard deviation and minimum and maximum values are shown for quantitative variables. Qualitative variables are shown as frequencies and proportions. Pearson's chi-squared test was used to determine whether there was a statistically significant difference between the expected frequencies and the observed frequencies in demographic vari-

ables, disease characteristics and treatment types (surgery: yes versus no; radiotherapy (RT): yes versus no; chemotherapy (CT): yes versus no).

Overall survival was calculated in months from date of diagnosis until date of death, or last information. Patients alive or lost to follow-up were censored (18 August 2019, was the end of follow-up). Survival curves were performed using the Kaplan-Meier method and compared with the log-rank test.

Hazard ratios (HRs) and $95 \%$ confidence intervals $(95 \% \mathrm{Cl})$ were calculated using Cox regression model for demographic variables, including sex (women and men), education (illiterate, incomplete elementary, complete elementary, high school and university education); disease characteristics, including tumour histology (squamous cell, adenocarcinoma, large cells, and other unspecified), CS (I/II, III and IV); treatment (surgery: alone or combined with RT, CT, other combinations; CT alone or combined with RT; RT; other combinations; no treatment). Level of significance was two-sided 5\% for all hypothesis tests. Analyses were performed using SPSS v.18 for Windows or Stata/MP 14.0 for Windows.

\section{Results}

\section{Characteristics of the study population}

The population of the study consisted of 17,422 patients diagnosed with NSCLC in the period from 2000 to 2009: 370 YA (YA: $2.2 \%), 8,697$ MA (MA: 49.9\%) and 8,355 elderlies (E: 48.0\%) (Table 1). The median age at diagnosis was 36 (YA), 56 (MA) and 72 years (E). The median and mean follow-up times were 7.95 months (minimum: 0.03-maximum: 220.22) and 17.47 months (SD: 27.55 months). Initially, we evaluated the percentage of patients diagnosed with NSCLC in each year of the 2000-2009 interval, according to the age groups, and YA consisted of $1.5 \%-2.7 \%$ along the years (Supplementary Figure 1).

Although among YA, almost half of the patients were females (48.1\% versus $51.9 \%$ males), in MA and elderlies, most patients were males (MA: 63.9\%; E: 71.5\%, $p<0.001$ ).

Regarding the education level, information was available for approximately $75 \%$ of the patients, in each age group. In the whole group, only 7.2\% reported University education. Besides that, there was a statistical difference among age groups and while more YA completed high school (29.5\%), illiteracy was predominant in the elderly group (15.0\%) $(p<0.001)$ (Table 1). Considering the histological type, adenocarcinoma was relatively more frequent, while squamous cell carcinoma was less frequent in the group of YA $(p<0.001)$. CS at diagnosis revealed a higher frequency of lung cancer diagnosed as metastatic disease (stage IV) in the group of YA (YA: 63.2\% versus MA: 51.9\% versus E: $43.2 \%$, $p<0.001$ ) (Table 1). 
Table 1. Characteristics of the study population.

\begin{tabular}{|c|c|c|c|c|c|c|}
\hline & \multirow[t]{2}{*}{ Age group } & $\begin{array}{c}\text { Young } \\
18-39 \text { years }\end{array}$ & $\begin{array}{c}\text { MA } \\
40-64 \text { years }\end{array}$ & $\begin{array}{c}\text { Elderly } \\
\geq 65 \text { years }\end{array}$ & Total & \multirow[t]{2}{*}{$p$-value } \\
\hline & & $n=370(\%)$ & $n=8,697(\%)$ & $n=8,355(\%)$ & $n=17,422(\%)$ & \\
\hline \multirow{2}{*}{$\begin{array}{l}\text { Age at } \\
\text { diagnosis }\end{array}$} & Mean (SD) & $34.6(4.5)$ & $55.3(6.3)$ & $72.6(5.6)$ & $63.1(11.2)$ & \multirow{2}{*}{ nd } \\
\hline & Median (min-max) & $36(30-39)$ & $56(40-64)$ & $72(65-99)$ & $64(20-99)$ & \\
\hline \multirow{2}{*}{ Sex } & Men & $192(51.9)$ & $5,560(63.9)$ & $5,970(71.5)$ & $11,722(67.3)$ & \multirow{2}{*}{$<0.001$} \\
\hline & Women & $178(48.1)$ & $3,137(36.1)$ & $2,385(28.5)$ & $5,700(32.7)$ & \\
\hline \multirow{6}{*}{ Education } & Illiterate & $5(1.8)$ & $408(6.3)$ & 935 (15.0) & $1,348(10.4)$ & \multirow{6}{*}{$<0.001$} \\
\hline & Incomplete elementary & $93(33.8)$ & $2,678(41.0)$ & $2,773(44.6)$ & $5,544(42.6)$ & \\
\hline & Complete elementary & 75 (27.3) & $1,913(29.3)$ & $1,584(25.5)$ & $3,572(27.4)$ & \\
\hline & High school & $81(29.5)$ & $971(14.9)$ & $566(9.1)$ & $1,618(12.4)$ & \\
\hline & University education & $21(7.6)$ & $558(8.5)$ & $357(5.7)$ & $936(7.2)$ & \\
\hline & Missing & 95 & 2,169 & 2,140 & 4,404 & \\
\hline \multirow{4}{*}{$\begin{array}{l}\text { Histological } \\
\text { type }\end{array}$} & Adenocarcinoma & $227(61.4)$ & $3,926(45.1)$ & $3,388(40.6)$ & $7,541(43.3)$ & \multirow{4}{*}{$<0.001$} \\
\hline & Squamous cells & 59 (15.9) & $2,492(28.7)$ & $2,842(34.0)$ & $5,393(31.0)$ & \\
\hline & Large cells & $8(2.2)$ & 209 (2.4) & $189(2.3)$ & $406(2.3)$ & \\
\hline & Other unspecified & $76(20.5)$ & $2,070(23.8)$ & $1,936(23.2)$ & $4,082(23.4)$ & \\
\hline \multirow{4}{*}{ CS } & $I-I I$ & $34(9.2)$ & $1,156(13.3)$ & $1,360(16.3)$ & $2,550(14.6)$ & \multirow{4}{*}{$<0.001$} \\
\hline & III & $84(22.7)$ & $2,670(30.7)$ & 2,891 (34.6) & $5,645(32.4)$ & \\
\hline & IV & 234 (63.2) & 4,516 (51.9) & $3,611(43.2)$ & 8,361 (48.0) & \\
\hline & Unknown & $18(4.9)$ & $355(4.1)$ & $493(5.9)$ & $866(5.0)$ & \\
\hline \multirow{3}{*}{ Treatment } & Surgery & $86(23.2)$ & $1,856(21.3)$ & $1,460(17.5)$ & 3,402 (19.5) & $<0.001$ \\
\hline & RT & $142(38.4)$ & 3,577 (41.1) & 2,931 (35.1) & $6,650(38.2)$ & $<0.001$ \\
\hline & CT & 265 (71.6) & $6,000(69.0)$ & $4,863(58.2)$ & $11,128(63,9)$ & $<0.001$ \\
\hline
\end{tabular}

Note: Education: $p$-value considering the five categories of education in the three age groups (excluding missing cases); Treatment: $p$-value considering patients treated with surgery (yes versus no), RT (yes versus no) and CT (yes versus no); min: Minimum; max: Maximum; nd: Not done

The main forms of treatment offered to patients, including surgery (yes versus no); RT (yes versus no) and CT (yes versus no) were analysed in the different age groups. The results revealed that a lower percentage of elderly patients received the main forms of treatment (compared with younger age groups) (Table 1). We further dissected this data, considering treatment within the CSs and observed that a higher percentage of young patients were treated with surgery in CSs I/II and III and with CT in CS I/II (than patients in older age groups). On the other hand, a lower percentage of elderly patients received surgery and CT in all CSs, but a higher percentage received RT in CSs I/II (than younger age groups) (Figure 3).

\section{Survival analysis}

Among 17,422 patients considered for the analysis, 16,639 had died at the end of the observation period (335 YA, 8,213 MA and 8,091 elderly). The probability of survival in 1, 2, 5 and 10 years was $37.5 \%, 18.9 \%, 7.4 \%$ and $3.8 \%$ for the whole group of patients (Table 2).

Overall survival was different among age groups, longer for YA $(p<0.001)$ (Figure 2). The median survival time was 7.98 months for all lung cancer patients and 8.41, 8.51 and 7.49 months for YA, MA and elderly people, respectively. Although the overall survival curves have runed together in the first months of follow-up, they distanced thereafter (Figure 2). In addition, YA had a longer overall survival in all the CSs (I/II, III and IV) (Figure 2). 


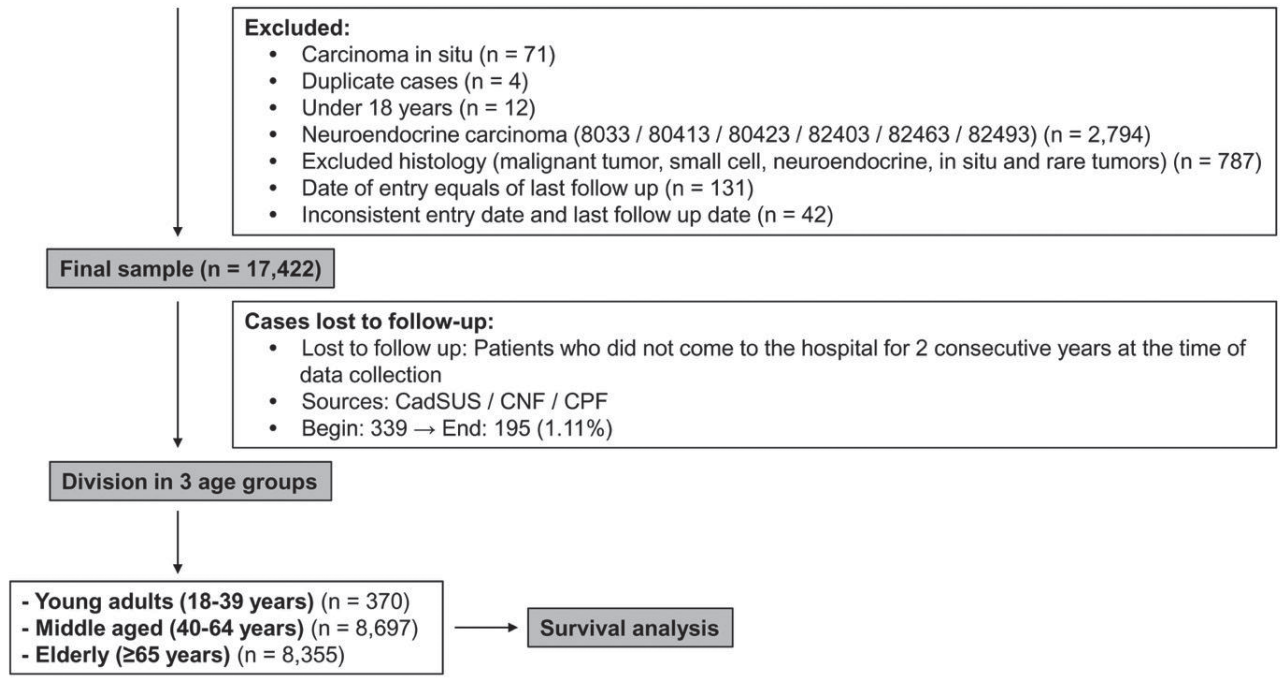

Figure 1. Summary of case selection, case exclusion and division on three age groups.
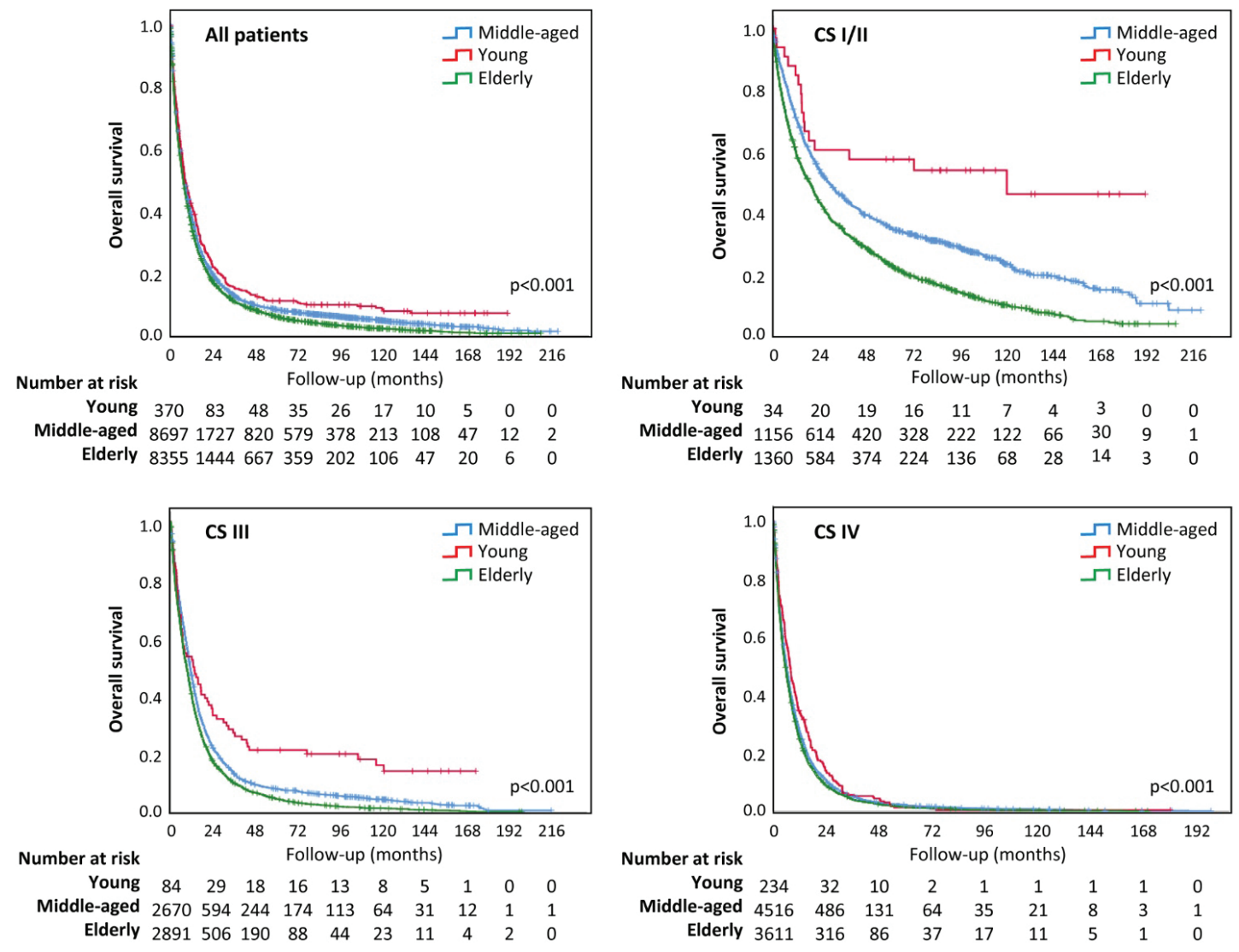

Figure 2. Overall survival according to age group. (a): Survival analysis for all patients; (b): Survival analysis for early CS (I/II); (c): Survival analysis for CS III; (d): Survival analysis for CS IV. 
Table 2. Median survival and probability of survival in 1, 2, 5 and 10-years.

\begin{tabular}{|l|l|c|c|c|c|c|}
\hline & & Median & \multicolumn{4}{|c|}{ Probability of cumulative survival (\%) } \\
\cline { 2 - 7 } & Variable & Months & 1-year & 2-years & 5-years & 10-years \\
\hline \multirow{4}{*}{ Age group } & Young & 8.41 & 42.5 & 22.8 & 11.2 & 9.0 \\
\cline { 2 - 7 } & MA & 8.51 & 39.0 & 20.1 & 8.5 & 5.0 \\
\cline { 2 - 7 } & Elderly & 7.49 & 35.7 & 17.5 & 6.2 & 2.4 \\
\cline { 2 - 7 } & Total & 7.98 & 37.5 & 18.9 & 7.4 & 3.8 \\
\hline
\end{tabular}
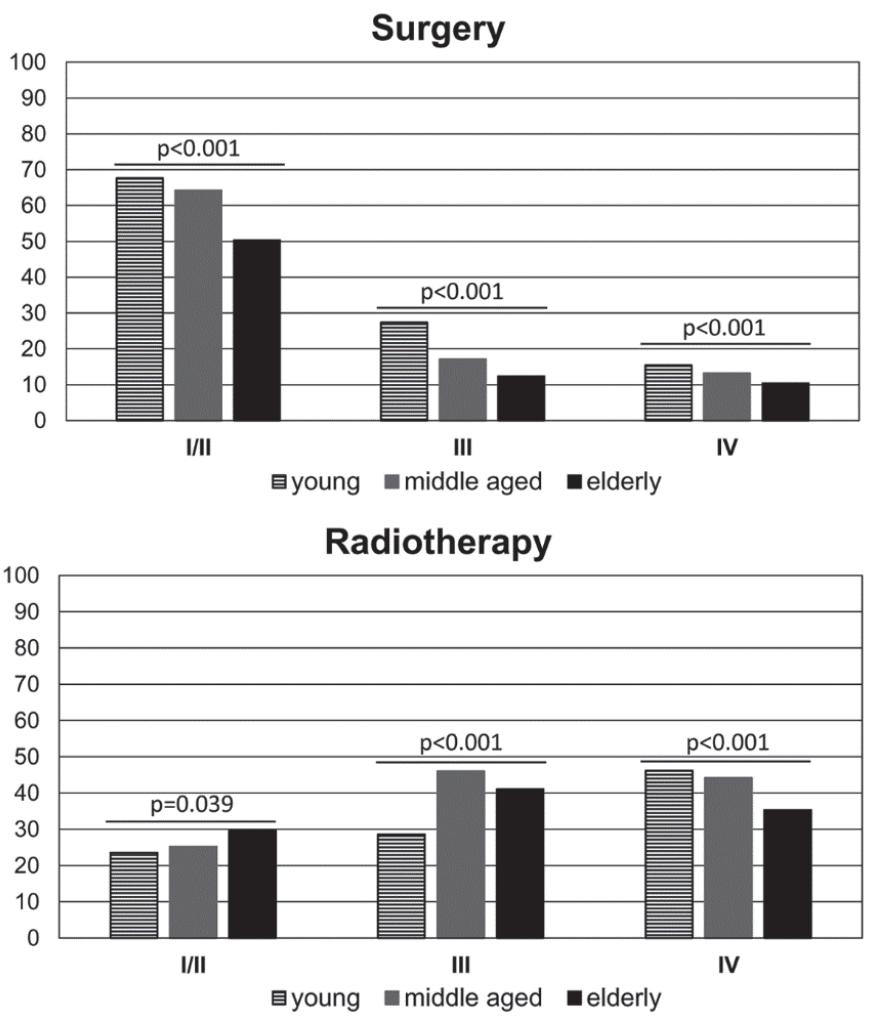

Chemotherapy

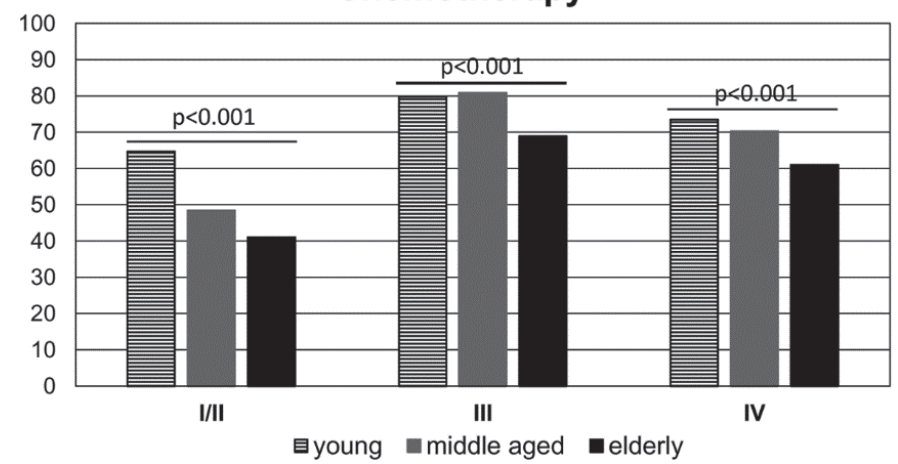

Figure 3. Percentage of patients treated with surgery, RT or CT according to the CS (CS I/II; III and IV) and the age group. 


\section{$H R$ of death - univariate and multivariable analysis}

We evaluated the HR of death considering sex, education level, histology, clinical staging and treatment in the three age groups. In univariate analysis, the prognostic factors for young individuals were education level, CS and treatment. In fact, complete elementary education and above (compared with incomplete elementary and illiteracy) were good prognostic factors, while advanced or metastatic disease (compared with early-stage disease - CSs I/II) was a poor prognostic factor in all three age groups. In addition, treatment with surgery (alone or in combinations) was a good prognostic factor for all age groups. Although sex and histological type were not prognostic factors for YA, male sex (compared with female) was a poor prognostic factor for MA and elderly patients, while adenocarcinoma histology (compared with squamous cell carcinoma) was a good prognostic factor in MA and elderly group (Table 3 ).

In multivariable analysis adjusted for age group, education, CS and type of treatment persisted as prognostic factors for all three age groups. Advanced stage and metastatic disease were poor prognostic factors compared with early-stage disease while surgery (alone or in combinations) was a good prognostic factor compared with other types of treatment for all the three age groups (Table 3). In addition, complete elementary education and above persisted as good prognostic factors for young and elderly and university education for MA patients. For MA and elderly individuals, male sex (compared with female) also persisted as a poor prognostic factor while adenocarcinoma histology (compared with squamous cell carcinoma) persisted as a good prognostic factor only for MA (Table 3).

Table 3. HR of death: univariate and multivariable analysis.

\begin{tabular}{|c|c|c|c|c|c|c|c|}
\hline \multicolumn{8}{|c|}{ Univariate analysis for probability of death non-adjusted for age group } \\
\hline & \multirow[b]{2}{*}{ Variable } & \multicolumn{2}{|c|}{$\begin{array}{c}\text { Young } \\
(n=263)\end{array}$} & \multicolumn{2}{|c|}{$\begin{array}{c}\text { MA } \\
(n=6,325) \\
\end{array}$} & \multicolumn{2}{|c|}{$\begin{array}{c}\text { Elderly } \\
(n=5,896)\end{array}$} \\
\hline & & $\mathrm{HR}(\mathrm{Cl} 95 \%)$ & $p$-value & $\mathrm{HR}(95 \% \mathrm{Cl})$ & $p$-value & $\mathrm{HR}(95 \% \mathrm{Cl})$ & $p$-value \\
\hline \multirow{2}{*}{ Sex } & Women & 1 & & 1 & & 1 & \\
\hline & Men & $1.11(0.90-1.38)$ & 0.327 & $1.24(1.19-1.30)$ & $<0.001$ & $1.19(1.13-1.25)$ & $<0.001$ \\
\hline \multirow{5}{*}{ Education } & Illiterate & 1 & & 1 & & 1 & \\
\hline & Incomplete elementary & $0.57(0.23-1.42)$ & 0.230 & $0.95(0.86-1.06)$ & 0.372 & $0.93(0.87-1.01)$ & 0.076 \\
\hline & Complete elementary & $0.34(0.13-0.85)$ & 0.021 & $0.84(0.75-0.94)$ & 0.002 & $0.83(0.77-0.90)$ & $<0.001$ \\
\hline & High school & $0.38(0.15-0.96)$ & 0.040 & $0.75(0.66-0.84)$ & $<0.001$ & $0.82(0.73-0.91)$ & $<0.001$ \\
\hline & University education & $0.25(0.09-0.68)$ & 0.007 & $0.65(0.57-0.74)$ & $<0.001$ & $0.68(0.60-0.77)$ & $<0.001$ \\
\hline \multirow{4}{*}{$\begin{array}{l}\text { Histological } \\
\text { type }\end{array}$} & Squamous cell & 1 & & 1 & & 1 & \\
\hline & Adenocarcinoma & $0.92(0.68-1.24)$ & 0.571 & $0.91(0.86-0.95)$ & $<0.001$ & $0.90(0.85-0.94)$ & $<0.001$ \\
\hline & Large cells & $1.02(0.46-2.24)$ & 0.968 & $1.10(0.96-1.28)$ & 0.179 & $1.26(1.08-1.46)$ & 0.003 \\
\hline & Other unspecified & $0.78(0.54-1.12)$ & 0.181 & $1.21(1.14-1.28)$ & $<0.001$ & $1.11(1.04-1.17)$ & 0.001 \\
\hline \multirow{3}{*}{ CS } & I/II & 1 & & 1 & & 1 & \\
\hline & III & $2.84(1.65-4.90)$ & $<0.001$ & $2.27(2.10-2.45)$ & $<0.001$ & $1.94(1.81-2.07)$ & $<0.001$ \\
\hline & IV & $5.63(3.35-9.47)$ & $<0.001$ & $3.67(3.40-3.96)$ & $<0.001$ & $2.80(2.62-3.00)$ & $<0.001$ \\
\hline \multirow{5}{*}{ Treatment } & $\begin{array}{l}\text { Surgery ( } \pm \mathrm{CT} ; \pm \mathrm{RT} ; \pm \mathrm{RT} \text { and } \\
\mathrm{CT} ; \pm \text { Other combinations) }\end{array}$ & 1 & & 1 & & 1 & \\
\hline & $\begin{array}{l}\mathrm{RT}( \pm \mathrm{CT} ; \pm \text { Other combina- } \\
\text { tions) }\end{array}$ & $2.28(1.66-3.13)$ & $<0.001$ & $2.23(2.09-2.37)$ & $<0.001$ & $1.74(1.63-1.86)$ & $<0.001$ \\
\hline & CT ( \pm Other combinations) & $2.35(1.72-3.22)$ & $<0.001$ & $2.39(2.23-2.55)$ & $<0.001$ & $2.04(1.90-2.18)$ & $<0.001$ \\
\hline & Other combinations & $1.25(0.45-3.43)$ & 0.671 & $4.05(3.42-4.81)$ & $<0.001$ & $3.62(3.11-4.21)$ & $<0.001$ \\
\hline & No treatment & $7.78(5.12-11.84)$ & $<0.001$ & $7.52(6.94-8.15)$ & $<0.001$ & $5.30(4.91-5.71)$ & $<0.001$ \\
\hline
\end{tabular}


Table 3. Continued

\begin{tabular}{|c|c|c|c|c|c|c|c|}
\hline \multicolumn{8}{|c|}{ Multivariable analysis for probability of death adjusted for age group } \\
\hline & \multirow[b]{2}{*}{ Variable } & \multicolumn{2}{|c|}{$\begin{array}{l}\text { Young } \\
(n=263)\end{array}$} & \multicolumn{2}{|c|}{$\begin{array}{c}\text { MA } \\
(n=6,325)\end{array}$} & \multicolumn{2}{|c|}{$\begin{array}{c}\text { Elderly } \\
(n=5,896)\end{array}$} \\
\hline & & $\mathrm{HR}(\mathrm{Cl} 95 \%)$ & $p$-value & $\mathrm{HR}(95 \% \mathrm{Cl})$ & $p$-value & $\mathrm{HR}(95 \% \mathrm{Cl})$ & $p$-value \\
\hline \multirow{2}{*}{ Sex } & Women & 1 & & 1 & & 1 & \\
\hline & Men & $1.08(0.84-1.40)$ & 0.542 & $1.26(1.20-1.33)$ & $<0.001$ & $1.22(1.15-1.29)$ & $<0.001$ \\
\hline \multirow{5}{*}{ Education } & Illiterate & 1 & & 1 & & 1 & \\
\hline & Incomplete elementary & $0.42(0.16-1.06)$ & 0.067 & $1.04(0.94-1.17)$ & 0.429 & 0.99 (0.91-1.07) & 0.716 \\
\hline & Complete elementary & $0.29(0.11-0.76)$ & 0.011 & $0.94(0.84-1.05)$ & 0.266 & $0.91(0.84-0.99)$ & 0.031 \\
\hline & High school & $0.31(0.12-0.81)$ & 0.017 & $0.91(0.80-1.03)$ & 0.130 & $0.89(0.80-0.99)$ & 0.036 \\
\hline & University education & $0.17(0.06-0.49)$ & 0.001 & $0.81(0.71-0.93)$ & 0.002 & $0.83(0.73-0.94)$ & 0.004 \\
\hline \multirow{4}{*}{$\begin{array}{l}\text { Histological } \\
\text { type }\end{array}$} & Squamous cell & 1 & & 1 & & 1 & \\
\hline & Adenocarcinoma & $0.70(0.48-1.02)$ & 0.062 & $0.91(0.85-0.97)$ & 0.002 & $0.95(0.89-1.01)$ & 0.095 \\
\hline & Large cells & $0.47(0.11-2.05)$ & 0.318 & $1.16(0.97-1.39)$ & 0.094 & $1.37(1.15-1.63)$ & $<0.001$ \\
\hline & Other unspecified & $0.89(0.56-1.40)$ & 0.610 & $1.11(1.04-1.20)$ & 0.003 & $1.04(0.97-1.12)$ & 0.257 \\
\hline \multirow{3}{*}{ CS } & I/II & 1 & & 1 & & 1 & \\
\hline & III & $3.24(1.65-6.37)$ & 0.001 & $1.80(1.63-1.99)$ & $<0.001$ & $1.70(1.55-1.85)$ & $<0.001$ \\
\hline & IV & $4.99(2.54-9.81)$ & $<0.001$ & $2.86(2.60-3.16)$ & $<0.001$ & $2.50(2.29-2.73)$ & $<0.001$ \\
\hline \multirow{5}{*}{ Treatment } & $\begin{array}{l}\text { Surgery ( } \pm \mathrm{CT} ; \pm \mathrm{RT} ; \pm \mathrm{RT} \text { and } \\
\mathrm{CT} ; \pm \text { Other combinations) }\end{array}$ & 1 & & 1 & & 1 & \\
\hline & $\begin{array}{l}\mathrm{RT}( \pm \mathrm{CT} ; \pm \text { Other combina- } \\
\text { tions) }\end{array}$ & $1.58(1.05-2.39)$ & 0.027 & $1.66(1.53-1.80)$ & $<0.001$ & $1.30(1.19-1.42)$ & $<0.001$ \\
\hline & CT ( \pm Other combinations) & $1.56(1.04-2.33)$ & 0.030 & $1.71(1.57-1.86)$ & $<0.001$ & $1.41(1.29-1.55)$ & $<0.001$ \\
\hline & Other combinations & $1.69(0.48-5.94)$ & 0.416 & $4.21(3.32-5.34)$ & $<0.001$ & $3.94(3.22-4.82)$ & $<0.001$ \\
\hline & No treatment & $7.76(4.26-14.16)$ & $<0.001$ & $5.43(4.90-6.01)$ & $<0.001$ & $4.31(3.91-4.76)$ & $<0.001$ \\
\hline
\end{tabular}

Note: HR: Hazard ratio; 95\% Cl: 95\% confidence interval

We further evaluated the HR of death for young individuals within each variable category (Table 4) compared with other age groups. Hazards of death was lower for young males, as well as for young individuals diagnosed within all CS groups (early stage, advanced or metastatic disease), as compared with the older age groups. In addition, YA treated with surgery or CT had a lower HR of death than elderly patients submitted to the same type of treatment, but it was not different from MA people. On the other side, there was no difference in hazards of death within the main histological types (squamous cell, adenocarcinoma and large cells) for young patients compared with MA and elderly patients. For patients treated with surgery and CT, the HR of death was higher for elderly patients (Table 4).

Table 4. Univariate analysis - HR of death for MA and elderly patients compared with young patients.

\begin{tabular}{|l|l|l|l|l|c|}
\hline \multicolumn{2}{|c|}{ Variable } & \multicolumn{1}{|c|}{ Age group } & HR & 95\% Cl & $p$-value \\
\hline \multirow{4}{*}{ Sex } & \multirow{4}{*}{ Male } & Young & & & \\
\cline { 3 - 6 } & & MA & 1.168 & $1.005-1.357$ & 0.043 \\
\cline { 3 - 6 } & & Elderly & 1.269 & $1.092-1.475$ & 0.002 \\
\cline { 3 - 6 } & \multirow{4}{*}{ Female } & Young & & & \\
\cline { 3 - 6 } & & MA & 1.053 & $0.898-1.236$ & 0.522 \\
\cline { 3 - 6 } & & Elderly & 1.199 & $1.021-1.406$ & 0.027 \\
\hline
\end{tabular}


Table 4. Continued

\begin{tabular}{|c|c|c|c|c|c|}
\hline \multirow{15}{*}{ Education } & \multirow{3}{*}{ Illiterate } & Young & & & \\
\hline & & MA & 0.522 & $0.216-1.264$ & 0.150 \\
\hline & & Elderly & 0.571 & $0.237-1.378$ & 0.213 \\
\hline & \multirow{3}{*}{$\begin{array}{l}\text { Incomplete } \\
\text { elementary }\end{array}$} & Young & & & \\
\hline & & MA & 0.861 & $0.697-1.062$ & 0.162 \\
\hline & & Elderly & 0.922 & $0.747-1.137$ & 0.447 \\
\hline & \multirow{3}{*}{$\begin{array}{l}\text { Complete } \\
\text { elementary }\end{array}$} & Young & & & \\
\hline & & MA & 1.332 & $1.043-1.700$ & 0.021 \\
\hline & & Elderly & 1.445 & $1.131-1.846$ & 0.003 \\
\hline & \multirow{3}{*}{ High school } & Young & & & \\
\hline & & MA & 1.019 & $0.802-1.293$ & 0.880 \\
\hline & & Elderly & 1.214 & $0.950-1.550$ & 0.121 \\
\hline & \multirow{3}{*}{$\begin{array}{l}\text { University } \\
\text { education }\end{array}$} & Young & & & \\
\hline & & MA & 1.435 & $0.884-2.330$ & 0.144 \\
\hline & & Elderly & 1.667 & $1.023-2.718$ & 0.040 \\
\hline \multirow{12}{*}{$\begin{array}{l}\text { Histological } \\
\text { type }\end{array}$} & \multirow{3}{*}{ Squamous cell } & Young & & & \\
\hline & & MA & 1.039 & $0.793-1.361$ & 0.781 \\
\hline & & Elderly & 1.185 & $0.906-1.553$ & 0.215 \\
\hline & \multirow{3}{*}{ Adenocarcinoma } & Young & & & \\
\hline & & MA & 1.005 & $0.874-1.155$ & 0.944 \\
\hline & & Elderly & 1.135 & $1.135-0.987$ & 0.076 \\
\hline & \multirow{3}{*}{ Large cells } & Young & & & \\
\hline & & MA & 1.116 & $0.524-2.378$ & 0.775 \\
\hline & & Elderly & 1.388 & $0.650-2.963$ & 0.397 \\
\hline & \multirow{3}{*}{$\begin{array}{l}\text { Other } \\
\text { unspecified }\end{array}$} & Young & & & \\
\hline & & MA & 1.588 & $1.240-2.034$ & $<0.001$ \\
\hline & & Elderly & 1.653 & $1.290-2.117$ & $<0.001$ \\
\hline \multirow{9}{*}{ CS } & \multirow{3}{*}{ I-II } & Young & & & \\
\hline & & MA & 2.021 & $1.234-3.319$ & 0.005 \\
\hline & & Elderly & 2.991 & $1.826-4.901$ & $<0.001$ \\
\hline & \multirow{3}{*}{ III } & Young & & & \\
\hline & & MA & 1.511 & $1.191-1.916$ & 0.001 \\
\hline & & Elderly & 1.832 & $1.444-2.323$ & $<0.001$ \\
\hline & \multirow{3}{*}{ IV } & Young & & & \\
\hline & & MA & 1.147 & $1.005-1.310$ & 0.042 \\
\hline & & Elderly & 1.238 & $1.084-1.415$ & 0.002 \\
\hline & \multirow{3}{*}{ Surgery } & Young & & & \\
\hline & & MA & 1.208 & $0.937-1.557$ & 0.145 \\
\hline & & Elderly & 1.512 & $1.171-1.951$ & 0.001 \\
\hline
\end{tabular}


Table 4. Continued

\begin{tabular}{|l|l|l|l|l|l|}
\hline \multirow{4}{*}{ Treatment } & \multirow{4}{*}{ RT } & Young & & & \\
\cline { 3 - 6 } & & MA & 0.977 & $0.823-1.160$ & 0.793 \\
\cline { 3 - 6 } & & Elderly & 0.984 & $0.828-1.168$ & 0.851 \\
\cline { 2 - 6 } & \multirow{3}{*}{ CT } & Young & & & \\
\cline { 3 - 6 } & & MA & 1.108 & $0.975-1.258$ & 0.117 \\
\cline { 3 - 6 } & & Elderly & 1.176 & $1.034-1.336$ & 0.013 \\
\hline
\end{tabular}

Note: HR: Hazard ratio; 95\% Cl: 95\% confidence interval

Treatment: Patients treated with surgery (yes versus no), RT (yes versus no) and CT (yes versus no)

\section{Discussion}

The present analysis focused on a cohort of 17,422 patients registered with NSCLC in the period of 2000-2009 at the hospital-based cancer registry from Sao Paulo State, Brazil. According to the present results, the group of YA, aged 18-39 years, corresponded to $2.1 \%$ of the whole group of patients, half were men, $61.4 \%$ were diagnosed with adenocarcinoma and $63.2 \%$ presented with metastatic disease. Compared with older age groups (MA: 40-64 years and elderly (E): > 64 years), less YA were illiterate; more YA were women and more YA were diagnosed with adenocarcinoma. Surgery, RT and CT were offered to $23.2 \%, 38.4 \%$ and $71.6 \%$ of the young patients. Although more YA had metastatic disease at diagnosis, they presented a longer overall survival than patients in the other age groups.

The present results are in accordance with other authors, who have shown that lung cancer in YA is more commonly detected in women and that adenocarcinoma is more prevalent than in older patients $[5,11,14]$. In addition, more advanced CS at diagnosis seems to be a trend in young patients [19]. Accordingly, among patients aged 40 years or less, a greater proportion (63.2\%, compared with $51.9 \%$ of MA and $43.2 \%$ of elderly patients, after excluding around $5 \%$ of the patients with undetermined CS) in the present series and $57.4 \%$ in a surveillance, epidemiology, and end results (SEER) study (compared with $43 \%$ of elderly individuals) were diagnosed with disease CS IV [5]. In a similar way, data from the Metropolitan Detroit Cancer Surveillance System, USA, showed that younger patients, less than 50 years, were less frequently diagnosed with local disease, i.e., 18.6\%, compared with elderly individuals (25.2\%) [4]. It seems likely young Brazilian patients are prone to present with metastatic disease at diagnosis. There is no clear explanation for this observation; however, lung cancer might have not been at first suspected, due to its rarity in young people, leading to a delay in diagnosis.

The median survival was quite poor in the three age groups, varying from 7.49 to 8.41 months. YA, in spite of being more frequently diagnosed with metastatic disease, lived longer than patients in older age groups. This effect was more pronounced in young patients diagnosed with disease CSs I/II and III, where a small proportion of individuals might reach durable remissions or even cure. This favourable outcome might be in part related with tumour genetics, as tumours from young patients more frequently harbour driver mutations that may be related with a better prognosis [20, 21]. In Brazil, data from a retrospective cohort study from the year 2014 indicate that around $50 \%$ of patients with metastatic adenocarcinoma were referred for molecular testing, among whom, $24 \%$ had a tumour with positive EGFR activating mutation and 87\% received an EGFR-tyrosine kinase inhibitor. Patients harbouring EGFR mutation positive tumours had a longer median overall survival; however, it was not possible to individualise outcomes, according to patient age [22]. In this study, even though most of the patients were treated in the public health system, availability of target therapy is rather variable along the country to the present date.

Other factors that may suggest a differential carcinogenesis pathway in YA are a lower smoking burden in pack-years and a higher frequency of non-smoking females, when compared to older patients $[9,11]$. In agreement, a recent study including 790 Brazilian lung cancer patients confirmed a less intense tobacco exposure in young patients ( $<55$ years), detected by lower pack-years, compared with older age groups. However, the percentage of smoking patients was high, around $80 \%$ in young, as well as in the other two older age groups [23]. Despite that, the percentage of adult smokers in Brazil has dropped from 34.8\% in 1989 to 12.6\% in 2019, due to reinforcement of restriction laws [24]. Another factor that may have contributed to poor overall survival in older patients diagnosed with CS I or CS II is the presence of comorbidities [5]. In the present series, curative intent treatment, such as surgery, was more frequently offered to young and MA individuals diagnosed with early-stage disease. In addition, CT was more frequently offered to younger age groups diagnosed with metastatic disease. Unfortunately, elderlies tend to be less frequently exposed to more aggressive treatments due to related poor treatment outcomes, such as postoperative complications, CT intolerance and mortality, which may be related with frailty and may be observed in more than half of older cancer patients [25]. 
In accordance with the present results, improved outcome has been shown for young patients in studies analysing data from hospital-based cancer registries [14], as well as SEER studies [4, 5] and others [6]. Some studies have already described a more pronounced 5-year overall survival advantage at earlier CSs of the disease that decreased in more advanced stages, with absolute differences between the younger and older groups reaching $25 \%$ for stages I and II, but only $9 \%$ and $2 \%$ for stages III and IV, respectively [4, 5]. In contrast, there are other studies that do not corroborate the difference in survival between young and elderly patients [11, 26] (Supplementary Table 1).

In the present study, the level of education was inversely associated with mortality. In accordance, a study evaluating cancer mortality in the United States according to educational level and race [27] showed a 2.84 to 3.36 higher death rate among men with lung cancer with $\leq 12$ years versus $>12$ years of education (for black and white ethnicities, respectively) and the same trend for women. In fact, the largest variability in cancer mortality associated with years of education was observed among lung cancer patients, when also considering cancer death rates for colorectal, breast or prostate cancer patients. This study, however, was restricted to individuals who were 25-64 years old at death. This is one of the main differences with the present study, as $48 \%$ of our population consisted of elderly people aged 65 years or more at cancer presentation. In addition, in our study, only a small part of the cohort, i.e. $7.2 \%$, had 12 or more years of education.

The current results indicate that even though a higher proportion of young patients (37.1\%) had education level above complete elementary grade than older age groups (MA: 23.4\%; elderly: 14.8\%), they (young) were more frequently diagnosed with metastatic disease. This data is in contrast with a previous study of our group, that showed an association between low education level and advanced stage of cancers [28]. A factor that may have contributed to this discrepancy is that, in this study, no consideration was given for the different age groups. In favour of our results, among young patients, other authors have already reported a greater proportion of metastatic disease at diagnosis [5]. In addition, education level has been increasing in Brazil along the years, indicating that higher education level is a trend in younger people [29], as we have observed. Thus, missing data for education level does not seem to have impacted the results.

The present data, however, may not reflect other regions of the country. São Paulo state, located in the southeastern region of Brazil, is the most populous state of the nation, with 43.93 million inhabitants (2018 estimate). The state presents an Human Development Index (HDI) of 0.833 and represents the third largest Gross Domestic Product (GDP) in Latin America in absolute figures, accounting for $32 \%$ of the national GDP [30-32].

In Brazil, every individual has the right to public health care and more than three-fourths of the Brazilian population benefit from the public healthcare system, Sistema Único de Saúde [33]. Cancer treatment in the public system is offered in comprehensive cancer care centres, called CACON, that offer treatment for all types of cancers, or in cancer care units, called UNACON, that offer treatment for the most prevalent cancers in Brazil, as well as associated General Hospitals, that perform oncological surgeries in the areas of Gynaecology, Mastology, Urology and Surgery of the Digestive System. São Paulo state cancer care network comprises 15 CACON, 50 UNACON, 6 general hospitals with oncological surgery and 3 RT specific units, distributed all over its territory [34]. All these public cancer units, as well some cancer care units of the private health care, contribute data to the hospital-based cancer registry run by FOSP, hence we may assume that the average population is well represented in the present series.

The strength of this study is the evaluation of a large database, summarising information from a large proportion of patients in a Brazilian state, with an organised health system. Limitations of the study include the absence of cancer specific survival data and information about smoking, family history, as well as comorbidities and molecular testing. Unfortunately, this data is neither available in other large databases in Brazil.

\section{Conclusion}

In conclusion, in this Brazilian cohort of NSCLC patients, YA presented a longer survival than older individuals. Besides representing only $2.1 \%$ of the whole group, a great concern is that a large proportion, i.e. more than one half of the young patients presented with metastatic disease. As a large fraction of YA might present tumours harbouring driver mutations, usually associated with better outcomes, biological differences among NSCLC patients in different age groups may in part contribute to the abovementioned findings.

\section{Acknowledgments}

The authors are very grateful to Maria Cristina Piñeiro Grandal, for editing the figures and Conselho Nacional de Desenvolvimento Científico e Tecnológico (CNPq) for support for M.A.A.K.F. 


\section{Funding}

This research did not receive any specific grant from funding agencies in the public, commercial or not-for-profit sectors.

\section{Conflicts of interest}

The authors declare no conflicts of interest.

\section{References}

1. Estimativa de incidência de Câncer no Brasil (2020) Ministério da Saúde, Instituto Nacional de Câncer José de Alencar Gomes da Silva (INCA) [https://www.inca.gov.br/numeros-de-cancer] Date accessed: 15/05/20

2. Siegel RL, Miller KD, and Jemal A (2020) Cancer statistics CA CancerJ Clin 70 7-30 https://doi.org/10.3322/caac.21590 PMID: 31912902

3. Cancer Research UK, Cancer Statics Reports for the UK (2020) [https://www.cancerresearchuk.org/health-professional/cancer-statistics/statistics-by-cancer-type/lung-cancer/incidence/] Date accessed: 01/04/20

4. Ramalingam S, Pawlish K, and Gadgeel S (1998) Lung cancer in young patients: analysis of a surveillance, epidemiology, and end results database J Clin Oncol 16 651-657 https://doi.org/10.1200/JCO.1998.16.2.651 PMID: 9469354

5. Subramanian J, Morgensztern D, and Goodgame B (2010) Distinctive characteristics of non- small cell lung cancer (NSCLC) in the young: a surveillance, epidemiology, and end results (SEER) analysis J Thorac Oncol 5 23-28 https://doi.org/10.1097/JTO.0b013e3181c41e8d

6. Radzikowska E, Roszkowski K, and Głaz P (2001) Lung cancer in patients under 50 years old Lung Cancer 33 203-211 https://doi. org/10.1016/S0169-5002(01)00199-4 PMID: 11551415

7. Costa GJ, Mello MJ, and Ferreira CG (2018) Increased incidence, morbidity and mortality rates for lung cancer in women in Brazil between 2000 and 2014: an analysis of three types of sources of secondary data Lung Cancer 125 77-85 https://doi.org/10.1016/j. lungcan.2018.09.005 PMID: 30429041

8. Jiang W, Kang Y, and Shi GY, et al (2011) Comparisons of multiple characteristics between young and old lung cancer patients Chin Med $J($ Engl) 125 72-80

9. Ak G, Metintas M, and Metintas S, et al (2007) Lung cancer in individuals less than 50 years of age Lung 185 279-286 https://doi. org/10.1007/s00408-007-9021-2 PMID: 17705064

10. Ye T, Pan Y, and Wang R (2014) Analysis of the molecular and clinicopathologic features of surgically resected lung adenocarcinoma in patients under 40 years old J Thorac Dis 6 1396-1402 PMID: 25364516 PMCID: 4215147

11. Tominaga K, Mori K, and Yokoi K, et al (1999) Lung cancer in patients under 50 years old Jpn J Cancer Res $90490-495$ https://doi. org/10.1111/j.1349-7006.1999.tb00774.x PMID: 10391087 PMCID: 5926099

12. Tian DL, Liu HX, and Zhang L (2003) Surgery for young patients with lung cancer Lung Cancer 42 215-220 https://doi.org/10.1016/ S0169-5002(03)00286-1 PMID: 14568689

13. Rich AL, Khakwani A, and Free CM (2015) Non-small cell lung cancer in young adults: presentation and survival in the English national lung cancer audit QJM 108 891-897 https://doi.org/10.1093/qjmed/hcv052 PMID: 25725079

14. Arnold BN, Thomas DC, and Rosen JE (2016) Lung cancer in the very young: treatment and survival in the national cancer data base $J$ Thorac Oncol 11 1121-1131 https://doi.org/10.1016/j.jtho.2016.03.023 PMID: 27103511

15. Araujo LH, Baldotto C, and de Castro G Jr, et al (2018) Lung cancer in Brazil J Bras Pneumol 44 55-64 https://doi.org/10.1590/s180637562017000000135 PMID: 29538545 PMCID: 6104542 
16. Fundação Oncocentro de São Paulo [http://www.fosp.saude.sp.gov.br/publicacoes/sobre] Date accessed: 13/01/20

17. Bleyer A, Barr R, and Hayes-Lattin B, et al (2008) Biology and clinical trials subgroups of the US national cancer institute progress review group in adolescent and young adult oncology The distinctive biology of cancer in adolescents and young adults Nat Rev Cancer 8 288-298 https://doi.org/10.1038/nrc2349 PMID: 18354417

18. United Nations, Department of Economic and Social Affairs, Population Division (2019) World population ageing 2019: highlights (ST/ ESA/SER.A/430) [https://www.un.org/en/development/desa/population/publications/pdf/ageing/WorldPopulationAgeing2019-Highlights.pdf] Date accessed: 21/06/20

19. Cormedi MCV, Lopes EFDT, and Maistro S, et al (2019) Clinical stage and histological type of the most common carcinomas diagnosed in young adults in a reference cancer hospital Clinics 73(Suppl. 1) e656s https://doi.org/10.6061/clinics/2018/e656s

20 Suidan AM, Roisman L, and Belilovski Rozenblum A, et al (2019) Lung cancer in young patients: higher rate of driver mutations and brain involvement, but better survival J Glob Oncol 5 1-8

21. Fang S and Wang Z (2014) EGFR mutations as a prognostic and predictive marker in non-small-cell lung cancer Drug Des Devel Ther 8 1595-1611 PMID: 25302015 PMCID: 4189714

22. Cronemberger E (2020) Real-world molecular testing and treatment patterns in Brazilian patients with newly diagnosed locally advanced or metastatic NSCLC Clinics 75 1980-5322 https://doi.org/10.6061/clinics/2020/e1777

23. Franceschini JP, Jamnik S, and Santoro IL (2017) Survival in a cohort of patients with lung cancer: the role of age and gender in prognosis J Bras Pneumol 43(6) 431-436 https://doi.org/10.1590/s1806-37562016000000298

24. INCA - Observatório da Política nacional de controle do tabaco - Dados e números da prevalência do tabagismo (2021) [https:// www.inca.gov.br/observatorio-da-politica-nacional-de-controle-do-tabaco/dados-e-numeros-prevalencia-tabagismo] Date accessed: $08 / 07 / 21$

25. Handforth C, Clegg A, and Young C, et al (2015) The prevalence and outcomes of frailty in older cancer patients: a systematic review Ann Oncol 26(6) 1091-1101 https://doi.org/10.1093/annonc/mdu540

26. Mauri D, Pentheroudakis G, and Bafaloukos D (2006) Non-small cell lung cancer in the young: a retrospective analysis of diagnosis, management and outcome data Anticancer Res 26 3175-3181 PMID: 16886653

27. Albano JD, Ward E, and Jemal A (2007) Cancer mortality in the United States by education level and race J Natl Cancer Inst 99 13841394 https://doi.org/10.1093/jnci/djm127 PMID: 17848670

28. Ribeiro K, Eluf Neto J, and Luizaga C, et al (2015) Low educational level is associated with advanced cancer stage in Brazil Int J Epidemiol 44(Suppl. 1) i3-i4 https://doi.org/10.1093/ije/dyv097.009

29. Agência IBGE - Notícias (2020) [https://agenciadenoticias.ibge.gov.br/agencia-sala-de-imprensa/2013-agencia-de-noticias/ releases/28285-pnad-educacao-2019-mais-da-metade-das-pessoas-de-25-anos-ou-mais-nao-completaram-o-ensino-medio] Date accessed: $13 / 07 / 21$

30. São Paulo População do Estado (2020) [http://www.bibliotecavirtual.sp.gov.br/temas/sao-paulo/sao-paulo-populacao-do-estado.php/] Date accessed: 08/08/20

31. Why São Paulo (2015) [https://www.en.investe.sp.gov.br/why-sao-paulo/diversified-economy/gdp/] Date accessed: 13/01/20

32. São Paulo é o Estado com melhor IDH (2013) [https://www.saopaulo.sp.gov.br/ultimas-noticias/sao-paulo-e-o-estado-com-melhoridh/] Date accessed: 13/01/20

33. Diretrizes Estratégicas, Ministério da Saúde (2020) [https://bvsms.saude.gov.br/bvs/pacsaude/diretrizes.php] Date accessed: 13/01/20

34. Unidades Habilitadas para atendimento em câncer no Estado de São Paulo (2020) [http://www.fosp.saude.sp.gov.br:443/epidemiologia/ docs/rede-Oncologia.pdf] Date accessed: 20/01/20 


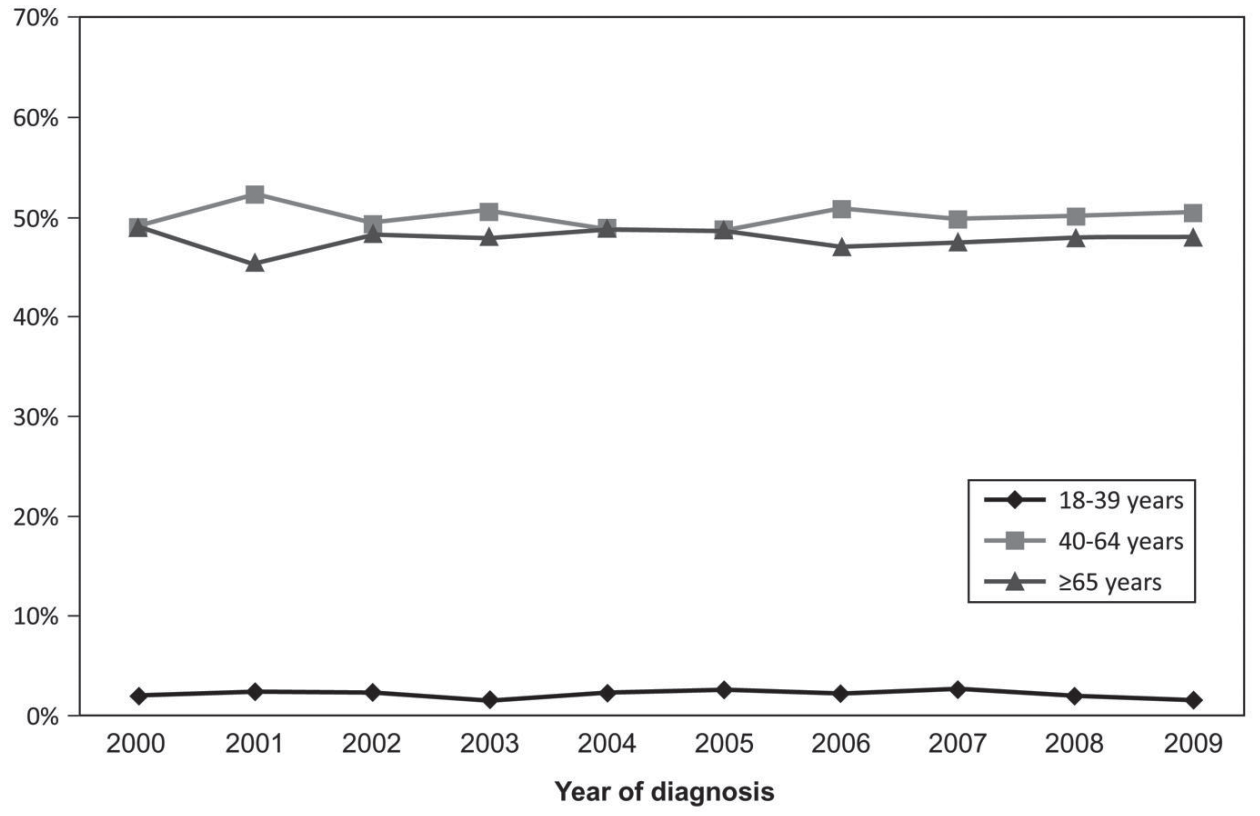

Supplementary Figure 1. Percentage of cases according to the age group and to the year of diagnosis.

Supplementary Table 1. Overall survival analysis in young patients.

\begin{tabular}{|c|c|c|c|c|c|c|c|c|c|}
\hline Study & $\begin{array}{c}\text { No. of } \\
\text { patients }\end{array}$ & $\begin{array}{c}\text { No. of young } \\
\text { patients }\end{array}$ & Cut off age & $\begin{array}{l}\text { Histology in } \\
\text { young (\%) }\end{array}$ & $\begin{array}{l}\text { Histology in } \\
\text { elderly (\%) }\end{array}$ & $\begin{array}{l}\text { Survival } \\
\text { analysis }\end{array}$ & $\begin{array}{l}\text { Survival in } \\
\text { young }\end{array}$ & $\begin{array}{l}\text { Survival in } \\
\text { elderly }\end{array}$ & $p$-value \\
\hline $\begin{array}{l}\text { Arnold et al [14] } \\
\text { (USA) }\end{array}$ & 173,856 & 5,657 & 46 & $\begin{array}{l}\text { A: } 49.2 \\
\text { S: } 15.7 \\
\text { L: } 5.7 \\
\text { O: } 29.3\end{array}$ & $\begin{array}{l}\text { A: } 39.2 \\
\text { S: } 29.9 \\
\text { L: } 4.1 \\
\text { O: } 26.8\end{array}$ & 5-years & $\begin{array}{l}\text { CS I: } 70 \% \\
\text { CS II: } 49 \% \\
\text { CS III: } 22 \% \\
\text { CS IV: } 5 \%\end{array}$ & $\begin{array}{l}\text { CS I: } 45 \% \\
\text { CS II: } 26 \% \\
\text { CS III: } 13 \% \\
\text { CS IV: } 3 \%\end{array}$ & $<0.0001$ \\
\hline $\begin{array}{l}\text { Subramanian } \\
\text { et al [5] (USA) }\end{array}$ & 239,088 & 2,775 & 40 & $\begin{array}{l}\text { A: } 57.5 \\
\text { S: } 12.5 \\
\text { L: } 10.3 \\
\text { O: } 19.7\end{array}$ & $\begin{array}{l}\text { A: } 45.2 \\
\text { S: } 26.4 \\
\text { L: } 7.6 \\
\text { O: } 20.8\end{array}$ & 5-years & \multicolumn{2}{|c|}{$\begin{array}{l}\text { Higher survival in young } \\
\text { patients in all CS comparing } \\
\text { with elderly }\end{array}$} & $<0.001$ \\
\hline $\begin{array}{l}\text { Mauri et al [26] } \\
\text { (Greece) }\end{array}$ & 1,906 & 115 & 45 & $\begin{array}{l}\text { A: } 48.7 \\
\text { S: } 23.5 \\
\text { L: } 10.4 \\
\text { O: } 15.7\end{array}$ & $\begin{array}{l}\text { A: } 42.7 \\
\text { S: } 36.5 \\
\text { L: } 54.9 \\
\text { O: } 11.7\end{array}$ & Median & $\begin{array}{c}12 \text { months } \\
(10.5-13.1)\end{array}$ & $\begin{array}{l}11.5 \text { months } \\
(10.9-12.2)\end{array}$ & 0.277 \\
\hline $\begin{array}{l}\text { Jiang et al [8] } \\
2012 \text { (China) }\end{array}$ & 3,320 & 626 & 45 & $\begin{array}{c}\text { A: } 37.7 \\
\text { S: } 21.1 \\
\text { L: } 0.3 \\
\text { SC: } 36.6 \\
\text { O: } 4.3\end{array}$ & $\begin{array}{c}\text { A: } 35.8 \\
\text { S: } 39.4 \\
\text { L: } 0.1 \\
\text { SC: } 21.1 \\
\text { O: } 3.6\end{array}$ & $\begin{array}{l}\text { 1-year } \\
\text { 3-years } \\
\text { 5-years }\end{array}$ & $\begin{array}{l}62.73 \% \\
23.97 \% \\
13.75 \%\end{array}$ & $\begin{array}{l}66.29 \% \\
30.71 \% \\
17.53 \%\end{array}$ & 0.0232 \\
\hline $\begin{array}{l}\text { Radzikowska et al } \\
\text { [6] (Poland) }\end{array}$ & 5,404 & 757 & 50 & $\begin{array}{l}\text { A: } 12.6 \\
\text { S: } 34.9 \\
\text { SC: } 22.9 \\
\text { O: } 29.6\end{array}$ & $\begin{array}{c}\text { A: } 7.6 \\
\text { S: } 42.0 \\
\text { SC: } 14.8 \\
\text { O: } 35.7\end{array}$ & 1-year & $32.60 \%$ & $28.90 \%$ & $<0.049$ \\
\hline
\end{tabular}


Supplementary Table 1. Continued

\begin{tabular}{|c|c|c|c|c|c|c|c|c|c|}
\hline $\begin{array}{l}\text { Tominaga et al } \\
\text { [11] (Japan) }\end{array}$ & 790 & 77 & 50 & $\begin{array}{c}\text { A: } 78.9 \\
\text { S: } 10.5 \\
\text { L: } 2.6 \\
\text { SC: } 7.9 \\
\text { O: } 1.3\end{array}$ & $\begin{array}{c}\text { A: } 49.4 \\
\text { S: } 35.1 \\
\text { L: } 2.7 \\
\text { SC: } 12.9 \\
\text { O: } 2.0\end{array}$ & $\begin{array}{l}\text { 2-years } \\
\text { 5-years }\end{array}$ & $\begin{array}{l}41.3 \% \\
33.0 \%\end{array}$ & $\begin{array}{l}41.8 \% \\
33.1 \%\end{array}$ & $\begin{array}{l}0.936 \\
0.769\end{array}$ \\
\hline $\begin{array}{l}\text { Ramalingam et al } \\
\text { [4] (USA) }\end{array}$ & 31,266 & 2,813 & 50 & $\begin{array}{c}\text { A: } 44.4 \\
\text { S: } 26.7 \\
\text { L: } 10.4 \\
\text { SC: } 17.4\end{array}$ & $\begin{array}{c}\text { A: } 33.7 \\
\text { S: } 37.9 \\
\text { L: } 7.4 \\
\text { SC: } 21.0\end{array}$ & 5-years & $16.10 \%$ & $13.40 \%$ & $<0.0001$ \\
\hline
\end{tabular}

Note: CS: Clinical stage; m: Months; No.: Number; Histology: A - Adenocarcinoma, S - Squamous cell carcinoma, L - Large cell carcinoma, SC - Small cell carcinoma, O - Other; Y: Years 